Original Article

\title{
Development of chitosan based microencapsulated spray dried powder of tuna fish oil: oil load impact and oxidative stability
}

\author{
Desenvolvimento de pó microencapsulado por pulverização de óleo de atum à base de \\ quitosana: impacto da carga de óleo e estabilidade oxidativa

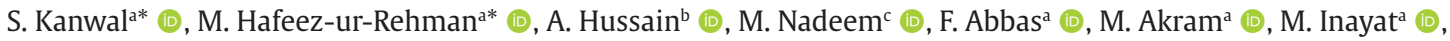 \\ F. Sughra ${ }^{a}$ (D) K. Ali ${ }^{\text {b }}$ (D) \\ aUniversity of Veterinary and Animal Sciences, Department of Fisheries and Aquaculture, Lahore, Pakistan \\ bUniversity of Veterinary \& Animal Sciences, Department of Wildlife \& Ecology, Lahore, Pakistan \\ 'University of Veterinary and Animal Sciences, Department of Dairy Technology, Lahore, Pakistan
}

\begin{abstract}
The impact of fish oil concentration on the oxidative stability of microcapsules through the spray drying process using chitosan and maltodextrin as wall material was studied. Emulsions were prepared with different Tuna fish oil (TFO) content (TFO-10\%, TFO20\%, TF030\% TF0-40\%) while wall material concentration was kept constant. Microencapsulated powder resulting from emulsion prepared with high fish oil load have high moisture content, wettability, total oil and low encapsulation efficiency, hygroscopicity and bulk tapped density. Oxidative stability was evaluated periodically by placing microcapsules at room temperature. Microcapsules prepared with TFO-10\% presented high oxidative stability in terms of peroxide value $(2.94 \pm 0.04)$ and anisidine value $(1.54 \pm 0.02)$ after 30 days of storage. It was concluded that optimal amounts of fish oil for microencapsulation are $10 \%$ and $20 \%$ using chitosan and maltodextrin that extended its shelf life during study period.
\end{abstract}

Keywords: microencapsulation, tuna fish oil, fish oil, emulsion, chitosan, oxidative stability.

\begin{abstract}
Resumo
Foi estudado o impacto da concentração de óleo de peixe na estabilidade oxidativa de microcápsulas por meio do processo de secagem por atomização, utilizando quitosana e maltodextrina como material de parede. As emulsões foram preparadas com diferentes teores de óleo de atum (TFO) (TFO-10\%, TFO20\%, TF030\% TF0-40\%), enquanto a concentração de material de parede foi mantida constante. O pó microencapsulado resultante da emulsão preparada com alta carga de óleo de peixe tem alto teor de umidade, molhabilidade e óleo total e baixa eficiência de encapsulação, higroscopicidade e densidade extraída a granel. A estabilidade oxidativa foi avaliada periodicamente colocando microcápsulas à temperatura ambiente. As microcápsulas preparadas com TFO- $10 \%$ apresentaram alta estabilidade oxidativa em termos de valor de peróxido $(2,94 \pm 0,04)$ e valor de anisidina $(1,54 \pm 0,02)$ após 30 dias de armazenamento. Concluiu-se que as quantidades ideais de óleo de peixe para microencapsulação são de $10 \%$ e $20 \%$ usando quitosana e maltodextrina que prolongaram sua vida útil durante o período de estudo.
\end{abstract}

Palavras-chave: microencapsulação, óleo de atum, óleo de peixe, emulsão, quitosana, estabilidade oxidativa.

\section{Introduction}

Markets trading in food are more inclined towards food that not only provide nutrients but also have positive effects in terms of healthier body. Food of this category is known as functional food and gaining importance in world further opening doors for research in this area. Fish oil from marine sources categorized as functional food due to its beneficial properties (Pourashouri et al., 2014). Marine fish oil constitutes of polyunsaturated fatty acids especially Eicosapentaenoic acid (EPA) and Decosahexaenoic acid (DHA) which are involved in resolving a number of issues related to heart, brain, immunity and inflammation
(Tzang et al., 2009; Balk et al., 2006). Dietary intake of fish oil should be increased to achieve the benefits of EPA and DHA. Tuna fish oil richest source of EPA and DHA owing to provide nutritional benefits as well as promoting health. It helps in reduction of cardiovascular diseases, cancer, allergy and proper development of brain and eye in infants (Troesch et al., 2020).

Most of primary energy in mammals is derived from fatty acids and additionally become part of their body structures. Fatty acids having many double bonds are polyunsaturated fats that provide many benefits related to

*e-mail: 2017-phd-2024@uvas.edu.pk; mhafeezurehman@uvas.edu.pk

Received: July 7, 2021 - Accepted: August 20, 2021 
health (Ganesan et al., 2014). Among plant sources Alpha Linolenic Acid (ALA) is PUFAs source while animal sources include marine fish that contain EPA and DHA as major PUFA. EPA and DHA are highly susceptible to oxidation due to their unsaturated nature. Reaction of lipids with oxygen resulting in compounds with unusual and rancid flavor also cause damage to health (Boerekamp et al., 2019). Such compound formation due to oxidation should be prevented to get maximum health benefits related to EPA and DHA.

To prevent the reactivity of active compounds in oil with water, oxygen and iron present in environment microencapsulation is well known technology (Onwulata, 2013). Concept of microencapsulation based on formation of protective barrier around the active ingredient and widely deployed in improvement and preservation of biological and functional element of food (Ray et al., 2016). Microencapsulation functions as a vehicle that carry active components, prevent oxidation and mask the properties like odor and taste that are not desired, so there is extensive use of this technique in food-based industries (Kak et al., 2019).

Selection of coating material for microencapsulation is crucial step. Polysaccharides, proteins and lipids are commonly used in formation of layer around oils rich in polyunsaturated fatty acids. Chitosan is a product resulting from $\mathrm{N}$-deacetylation of chitin is extensively applied in food industry for microencapsulation due to its edible nature, biodegradability, non-toxic, cheap, antioxidant and antimicrobial properties (Prashanth and Tharanathan, 2007). Chitosan produce gels with higher stability and firmness that prevent leakage of active compounds (Vishnu et al., 2017).

Lipids can be microencapsulated using many techniques like spray drying (Chang et al., 2006), freeze drying, complex coacervation (Lazko et al., 2004), supercritical fluid precipitation (Martin et al., 2010), and emulsion extrusion process (Yuliani et al., 2006). Spray drying is cheap and common method to encapsulate fish oil using polysaccharide or combination of wall materials. Conversion of active food ingredient in powder through spray drying proved to be handled easily with enhanced biological stability (Sansone et al., 2011; Turchiuli et al., 2005).

Factors like variety of wall material, characteristics of core material and its concentration, emulsion to be used and spray dryer chamber conditions have a major impact on microencapsulation (Labuschagne, 2018). These parameters should be evaluated in order to get lower surface oil in microcapsuled powder.

Protection of fish oil from oxidation and to achieve maximum health advantages, present study was focused on the concentration of fish oil and its impact on microencapsulation employing spray drying technique and chitosan as coating material. Emulsion prepared with different oil concentrations was evaluated in terms of bulk density, viscosity and stability. Produced particles were subjected to encapsulation efficiency, surface oil and oxidation analysis.

\section{Materials and Methods}

\subsection{Biological material}

TFO was extracted from tissue of tuna fish through direct steaming method and oil was employed as core material while chitosan was utilized as coating material along with maltodextrin.

\subsection{Emulsion formation}

Chitosan and maltodextrin were dissolved in distilled water overnight at room temperature before emulsion formation in order to obtain a saturated polymer of these molecules. TFO was added gradually in solution and blended using homogenizer at $3500 \mathrm{rpm}$ for 10 minutes. Coating materials (chitosan: maltodextrin) were added in a 1:1 ratio. Concentration of wall material was secured at $30 \%(\mathrm{w} / \mathrm{w}$ ) while core material concentration being used was $10 \%, 20 \%, 30 \%$ and $40 \%(w / w)$.

\subsection{Emulsion properties}

Emulsion with different oil concentrations were characterized in terms of percent separation, viscosity and mean droplet size. After formation of emulsion $25 \mathrm{ml}$ from each sample was transferred to graduated cylinder and stored at room temperature. Percent separation was calculated according to Formula 1 as:

$$
\% \text { separation }=\left(H_{1} / H_{0}\right) 1000
$$

$\mathrm{H}_{1}$ denotes the preliminary height of emulsion while $\mathrm{H}_{0}$ is height of upper point (Aguiar et al., 2016).

Emulsion viscosity was calculated using rheometer (Brook field, Dv2).

\subsection{Spray drying}

For microencapsulation, laboratory scale mini spray dryer (Toption Lab Spray Dryer, Xi'an, China) was used. Spray dryer operating factors were set as following: inlet temperature $180 \pm 2{ }^{\circ} \mathrm{C}$, outlet temperature $85 \pm 2{ }^{\circ} \mathrm{C}$, emulsion feed rate $0.7 \mathrm{~L} / \mathrm{h}$ and air flow rate $250 \mathrm{~kg} \mathrm{~h}^{-1}$ (Linke et al., 2021). Fish oil microcapsules obtained retaining single cyclone separator, packaged, and stored at room temperature.

\subsection{Characterization of microcapsules}

\subsubsection{Moisture content}

Microcapsules in powder form were evaluated in terms of moisture content gravimetrically by drying powder in an oven at $105^{\circ} \mathrm{C}$ (Wenyao et al., 2016).

\subsubsection{Wetability}

Barros Fernandes et al. (2014) method was used for the determination of wettability in microcapsule powders. $100 \mathrm{~mL}$ of distilled water was taken followed by sprinkling of $1 \mathrm{~g}$ powder avoiding agitation at $20^{\circ} \mathrm{C}$. Comparison of wettability between samples was calculated through time taken by different samples in sinking, submerging and disappearance from surface of water. 


\subsubsection{Solubility}

Solubility of powder was evaluated by employing method of Cano-Chauca et al. (2005). Powder (1g) was added in $25 \mathrm{~mL}$ distilled water and stirred using a blender for $5 \mathrm{~min}$ followed by centrifugation for $10 \mathrm{~min}$ at $3000 \mathrm{rpm}$. Resulting supernatant was separated and $20 \mathrm{~mL}$ of it was put in a petri dish already weighted. These samples were oven dried $\left(105^{\circ} \mathrm{C}\right)$ overnight and weight difference was used for calculation of solubility (\%).

\subsubsection{Hygroscopicity}

Hygroscopicity was determined following the procedure described by Cai and Corke (2000) with some amendments. $1 \mathrm{~g}$ of powder from each sample was put in saturated $\mathrm{NaCl}$ solution separately at $25{ }^{\circ} \mathrm{C}$ for a period of one week. Samples were weighted again and hygroscopicity evaluated as the absorbance of moisture in grams per total dry weight of solids (g/100g).

\subsubsection{Bulk tapped density}

Powder (5g) was transferred to a graduated cylinder of $25 \mathrm{~mL}$ capacity. Cylinder was dropped and lifted repeatedly until a difference was observed between different measurement of volume. Bulk density was calculated as mass of powder and its apparent volume $\mathrm{mV}^{-1}$ (Goula and Adamopoulos, 2008).

\subsubsection{Total oil and oil retention}

Microcapsule powder $(0.5 \mathrm{~g})$ from each sample was mixed with $2 \mathrm{~mL}$ of acetate buffer ( $\mathrm{pH} 3.0)$ and vortexed for 2-3 min. Extraction of sample was performed using $25 \mathrm{~mL}$ hexane and isopropanol solution of 3:1 ratio and followed by centrifugation for $15 \mathrm{~min}$ at $2000 \mathrm{rpm}$ for a period of $10 \mathrm{~min}$. Solvent was again used for the re-extraction of aqueous phase after separation of organic phase. Contents were filtered through anhydrous $\mathrm{Na}_{2} \mathrm{So}_{4}$ and transferred to rotatory evaporator at $70{ }^{\circ} \mathrm{C}$. The resulting content was dried in an oven at $105{ }^{\circ} \mathrm{C}$ and total oil was measured gravimetrically (Baik et al., 2004). Oil retention was calculated by total oil per initial oil load.

\subsection{Oxidative stability}

\subsubsection{Peroxide value (PV)}

Bligh and Dyer (1959) method was used for extraction of oil from powdered microcapsules. Peroxide value was determined using spectrophotometric method. Briefly, chloroform/methanol $(7: 3 \mathrm{v} / \mathrm{v})$ solution was added to oil extracted from powder followed by addition of iron II chloride and Sodium thiocyanate solution. Resulting mixture was incubated at room temperature for $5 \mathrm{~min}$ and readings were taken at $550 \mathrm{~nm}$ and expressed as meq $\mathrm{O}_{2}$ per kg of oil (Rahmani-Manglano et al., 2020).

\subsubsection{Anisidine value}

Anisidine value was measured for evaluation of secondary oxidation products using AOCS Official Methods.

\subsubsection{Tocopherol content}

Tocopherol content of powder microcapsules was assessed using American Oil Chemist Society protocol by HPLC (AOCS, 1998). Measurements were calculated by authentic standard and run in duplicates. Tocopherol content was expressed in $\mu \mathrm{g} / \mathrm{g}$ of oil.

\subsection{Statistical analysis}

Values in each table, figure and results were designated as mean \pm standard deviation in terms of replications. DMR test applied using statistical software SAS 1.1 to analyze the differences between means and letters indicated the statistically significant differences among samples to be studied.

\section{Results}

Table 1 depicts the summary of physical properties of emulsion prepared with different oil load. Emulsion having high oil content were more viscous as compared to those developed with low content of fish oil. High viscosity (92.77 $\pm 0.14 \mathrm{mPa}$ s.) recorded for emulsion prepared with $10 \%$ oil load attributed to more solid content in it. While emulsion prepared with $40 \%$ oil load has low viscosity $66.21 \pm 1.87 \mathrm{mPa}$ s. Encapsulation yield is dependent on total solid content of emulsion which in turn effects the viscosity. Emulsion with more solid content shown to be more viscous thus preventing the movements of active material inside it due to quick protective layer formation over it.

\subsection{Emulsion stability}

Emulsion stability is an indicator for determining efficiency of encapsulation agents. Emulsion prepared with $10 \%$ and $20 \%$ fish oil concentration were kinetically stable for 30 days storage and no phase separation observed in them. While formulations prepared with $30 \%$ and $40 \%$ oil load proved to be unstable due to little phase

Table 1. Properties of emulsion to be fed for spray drying.

\begin{tabular}{ccccc}
\hline Oil load (\%) & Separation (\%) & Viscosity (mPa.s) & Mean diameter $(\mu \mathrm{m})$ \\
\hline TFO-10\% & - & $92.77 \pm 0.14^{\mathrm{a}}$ & $1541.34 \pm 3.11^{\mathrm{d}}$ \\
TFO-20\% & - & $86.96 \pm 0.84^{\mathrm{b}}$ & $1752.78 \pm 10.52^{\mathrm{c}}$ \\
TFO-30\% & 1.72 & $81.76 \pm 0.15^{\mathrm{c}}$ & $2161.10 \pm 9.72^{\mathrm{b}}$ \\
TFO-40\% & 3.89 & $66.21 \pm 1.87^{\mathrm{d}}$ & $2366.53 \pm 1.56^{\mathrm{a}}$ & \\
\hline
\end{tabular}

Means with in a column having indifferent letters for paramerters were considered as significant at $\mathrm{p}<0.05$. 
separation recorded in them. Formulation four has more phase separation explained because of oil content in it as compared to third formulation with $3.89 \%$ and $1.72 \%$ phase separation respectively.

\subsection{Emulsion droplet size}

Higher mean droplet size recorded was $2366.53 \pm 1.56 \mu \mathrm{m}$ for emulsion with $40 \%$ oil load while emulsions with $10 \%$, $20 \%$ and $30 \%$ oil load has $1541.34 \pm 3.11,1752.78 \pm 10.52$, $2161.10 \pm 9.72$ mean droplet size respectively. Chitosan was in low amount in emulsion prepared with $40 \%$ of fish oil as compared to emulsions prepared with lower concentration of fish oil. Large mean droplet size is attributed to merging of droplets in oil water interface and droplets becomes enlarged. Large droplet size effect the microencapsulation efficiency and flavor of active material.

\subsection{Microcapsules characterization}

Moisture content is an important factor regarding microencapsulation of active material as it effects the shelf life and quality of microcapsules. Moisture content of microcapsules with different oil to matrix ratio showed significant differences among them and ranged between $3.86 \pm 0.01$ and $5.0 \pm 0.01$. chitosan based microcapsules were not wet and their moisture was within acceptable range. Lowest moisture content was observed for formulation powders prepared with $30 \%$ of fish oil. Results revealed that different concentration of fish oil had an impact on moisture content.

\subsection{Wettability}

Absorption of water by microcapsules is an important property regarding powder characterization and refurbishing wettability is dependent on porosity, density and presence on certain substances over powder surface. In current study different formulation taken different time to be completely wet and ranged between $685.4 \mathrm{~s}$ and $1550.1 \mathrm{~s}$ (Table 2). Wettability is minimum in powder formed from $10 \%$ oil emulsion. Low oil concentration in powder effect the hydrophobicity of microcapsules that resulted in low wettability. Hydrophobic components present on the outer surface of microcapsules influenced the wettability. Wall material also impact on wettability as low concentration of wall material in composition 4 with relation to oil produced less dense powder which further allow water penetration and high wettability.

\subsection{Encapsulation efficiency}

Encapsulation efficiency recorded for different samples chronicled in Table 2. Concentration of oil influenced encapsulation efficiency of microcapsules negatively. Higher ratio of active material in relation to chitosan decreased the encapsulation efficiency of powder due to presence of surface oil over it. Microcapsules prepared with low oil load were shown to be efficiently encapsulate the active material. Highest encapsulation efficiency was recorded for TFO (10\%) (91.27 \pm 0.05$)$.

\subsection{Solubility}

Solubility is the measure of quality in food ingredients. Microcapsules having good soluble property are considered as of superior quality. Impact of oil quantity on solubility is given in Table 2. Microcapsules prepared with low oil content expressed high solubility value as compared to those formed from high oil load and ranged from $48.20 \%$ and $41.25 \%$. It is concluded that microcapsules solubility is related to oil concentration and wall material used for encapsulation.

\subsection{Hygroscopicity}

The capacity to absorb moisture from environment is measured through hygroscopicity. In current study hygroscopicity ranged between $12.65-13.45 \%$. Higher value of this property was observed for formulation made with low oil content. It means low oil load has more content of coating material that was involved in absorption of moisture. There was not efficient absorption of moisture in formulation 3 and 4, it could produce off flavors in microcapsules.

\subsection{Bulk tapped density}

Results obtained for bulk tapped density were $0.45 \mathrm{mg} \mathrm{L}^{-1}$, $0.42 \mathrm{mg} \mathrm{L}^{-1}, 0.38 \mathrm{mg} \mathrm{L}^{-1}, 0.29 \mathrm{mg} \mathrm{L}^{-1}$ for $10 \% 20 \%, 30 \%$ and $40 \%$ oil load respectively. It is evident that concentration of oil has strong impact on the value of this variable. Density is lower in powder with low oil content which is also related to ratio of coating material with the core.

\subsection{Oxidative stability}

Oxidation of lipids in fish oil microcapsules assessed during different storage intervals. PV is used for determination of primary products produced as a result

Table 2. Characteristics of microcapsule prepared from infeed emulsions having different fish oil content.

\begin{tabular}{|c|c|c|c|c|c|c|c|}
\hline Fish Oil load & $\begin{array}{c}\text { Moisture } \\
\text { content (\%) }\end{array}$ & $\begin{array}{l}\text { Wetability } \\
(s)\end{array}$ & $\begin{array}{l}\text { Encapsulation } \\
\text { efficiency (\%) }\end{array}$ & $\begin{array}{c}\text { Solubility } \\
(\%)\end{array}$ & $\begin{array}{l}\text { Hygroscopicity } \\
(\%)\end{array}$ & $\begin{array}{c}\text { Bulk tapped } \\
\text { density } \\
\left(\mathrm{gm} \mathrm{L}^{-1}\right)\end{array}$ & Total oil (\%) \\
\hline TFO (10\%) & $5.0 \pm 0.01^{\mathrm{a}}$ & $685.41 \pm 5.01^{\mathrm{d}}$ & $91.27 \pm 0.05^{\mathrm{a}}$ & $48.20 \pm 0.00^{\mathrm{a}}$ & $13.45 \pm 0.05^{\mathrm{a}}$ & $0.45 \pm 0.01^{\mathrm{a}}$ & $0.84 \pm 0.02^{\mathrm{d}}$ \\
\hline TFO (20\%) & $4.33 \pm 0.02^{\mathrm{b}}$ & $816.5 \pm 5.50^{c}$ & $87.74 \pm 0.08^{b}$ & $42.45 \pm 0.75^{b}$ & $13.10 \pm 0.00^{\mathrm{b}}$ & $0.42 \pm 0.01^{\mathrm{b}}$ & $0.91 \pm 0.01^{c}$ \\
\hline TFO (30\%) & $3.86 \pm 0.01^{\mathrm{d}}$ & $1456.0 \pm 0.0^{\mathrm{b}}$ & $81.84 \pm 0.08^{c}$ & $42.70 \pm 0.00^{\mathrm{b}}$ & $12.80 \pm 0.00^{c}$ & $0.38 \pm 0.01^{c}$ & $0.97 \pm 0.01^{b}$ \\
\hline TFO (40\%) & $3.92 \pm 0.01^{c}$ & $1550.1 \pm 27.5^{\mathrm{a}}$ & $71.82 \pm 0.53^{d}$ & $41.25 \pm 0.05^{c}$ & $12.65 \pm 0.01^{\mathrm{d}}$ & $0.29 \pm 0.01^{\mathrm{d}}$ & $1.14 \pm 0.01^{\mathrm{a}}$ \\
\hline
\end{tabular}

Means within same column with different letters are considered as statistically significant at $\mathrm{p}<0.05$. TFO $10 \%$ : microcapsules prepared with $10 \%$ tuna fish oil; TFO 20\%: microcapsules prepared with $20 \%$ tuna fish oil; TFO $30 \%$ : microcapsules prepared with $30 \%$ oil tuna fish oil; TFO $40 \%$ : microcapsules prepared with $40 \%$ tna fish oil. 
of lipid oxidation. PV values noted after the production of microcapsules were $2.47 \pm 0.01,2.84 \pm 0.01,2.91 \pm 0.02$, $2.39 \pm 0.05$ ( $\mathrm{meq} \mathrm{O}_{2} / \mathrm{kg}$ oil) for TFO- $10 \%$, TFO- $20 \%$, TFO- $30 \%$, TFO-40\% respectively. There is significant difference observed in PV at 0 days between samples having different oil content. An increase in hydroperoxide content was indicated when compared with PV of fresh oil ( 0.79 meq $\mathrm{O}_{2} / \mathrm{kg}$ oil). Ascending trend in PV of microcapsules after formation is attributed to operating conditions of spray drying machine (feed rate, temperature of inlet, shear stress, heat) that resulted in oxidation. Highest PV was observed after 30 days of storage for microcapsules prepared with $40 \%$ oil load. This high PV is explained on the basis of surface oil present on microcapsules prepared from emulsions having high content of oil that reacted with oxygen in air thus produced hydroperoxides. There was a linear increasing trend in hydroperoxide per kilogram of powder encapsulated oil during storage period. Highest hydroperoxide concentration noted after 30 days of storage period for powder with $40 \%$ oil load followed by $30 \%, 20 \%$ and $10 \%$. There was not any significant difference among PV of formulations prepared with $20 \%$ and $30 \%$ oil concentration.

Anisidine values recorded at different storage intervals for microcapsules having different oil content. Lowest anisidine values of $1.24,1.41,1.47,1.54$ were observed at 0 day, after 10 days, 20 days and 30 days respectively for microcapsules loaded with $10 \%$ of fish oil. Powders from other formulations showed an elevation in anisidine value at high oil content. Significant differences were observed among powders having different oil loads. The highest values $(8.21 \pm 0.07)$ of anisidine were noted after 30 days for powders formed with $40 \%$ oil load. Therefore, it is supposed that these pronounced differences in anisidine value were caused by emulsion antioxidant activity (Figure 1 and Table 3).

Tocopherol is an important parameter for assessing the oxidative status of an oil Galeano Díaz et al. (2006). In current study oxidative stability was evaluated through PV, AV and additionally through quantification of tocopherols. Alpha, beta, gamma and delta tocopherol content observed for microcapsules of fish oil. There was

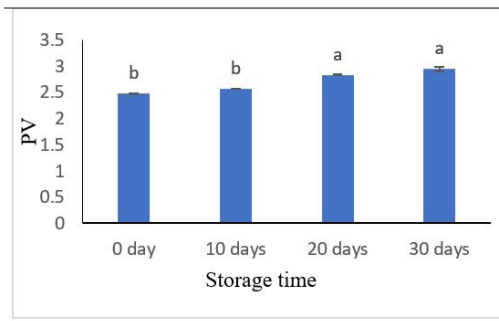

(a)

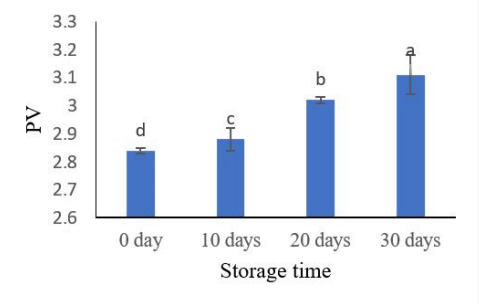

(b)

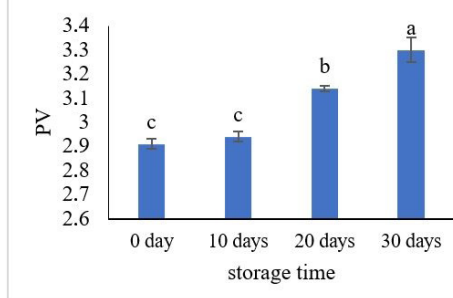

(c)

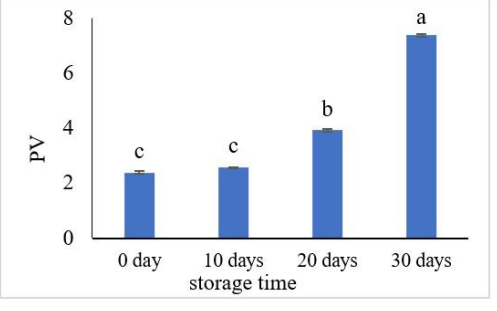

(d)

Figure 1. Oxidative stability (PV) of microencapsulated TFO after different storage intervals. (a) Microencapsulated powder with $10 \%$ TFO (b) Microencapsulated powder with 20\% TFO (c) Micoencapslated powder with 30\% TFO (d) Microencapsulated powder with $40 \%$ TFO.

Table 3. Evaluation of oxidative stability at different storage intervals.

\begin{tabular}{|c|c|c|c|c|}
\hline \multirow{2}{*}{ Formulations } & \multicolumn{4}{|c|}{ Anisidine value (AV) (meq $\mathrm{O}_{2} / \mathbf{k g}$ oil) } \\
\hline & 0 day & 10 days & 20 days & 30 days \\
\hline TFO-10\% & $1.24 \pm 0.01^{\mathrm{d}}$ & $1.41 \pm 0.02^{\mathrm{d}}$ & $1.47 \pm 0.06^{c}$ & $1.54 \pm 0.02^{\mathrm{d}}$ \\
\hline TFO-20\% & $2.53 \pm 0.02^{c}$ & $2.75 \pm 0.01^{\mathrm{c}}$ & $2.95 \pm 0.03^{b}$ & $3.17 \pm 0.0^{c}$ \\
\hline TFO-30\% & $2.95 \pm 0.30^{\mathrm{b}}$ & $3.06 \pm 0.05^{b}$ & $3.18 \pm 0.01^{b}$ & $3.46 \pm 0.05^{\mathrm{b}}$ \\
\hline TFO-40\% & $4.92 \pm 0.21^{\mathrm{a}}$ & $5.65 \pm 0.02^{\mathrm{a}}$ & $6.45 \pm 0.26^{\mathrm{a}}$ & $8.21 \pm 0.07^{a}$ \\
\hline
\end{tabular}

Means within a column having indifferent letters were considered statistically significant. 
significant difference noted in the microcapsules loaded with high fish oil content. Alpha tocopherol was found abundantly in all studied formulations.

\section{Discussion}

Microencapsulation is an emerging technology to cover bioactive substances like omega-3 and enhance their stability and shelf life. Oil with high content of omega-3 is prone to oxidation therefore encapsulation is done to avoid its contact with air and improving their transfer and obtain nutrients for a healthy life style. Current study was based on different concentration of omega-3 enriched oil microecapsules preparation using chitosan and their storage study. Chitosan is a thickening agent that tributed to high viscosity in emulsion with $10 \%$ oil. Similar results were reported by Yu et al. (2007). while using sodium caseinate and maltodextrin. They found that viscosity decreased in emulsions having high oil concentration. On the other hand, highly viscous emulsions were difficult to be fed in spray dryer and resulted in slow rate atomization (Adamiec and Kalemba, 2006). Chitosan is a good encapsulating agent that resulted in low values of phase separation in treatments being studied. Viscosity is also an important factor related to emulsion droplet size. Emulsions with low viscosity allow the movements of droplets inside them results in their flocculation and diameter of droplet is increased. Whereas emulsions with high viscosity do not allow circular movements inside the droplets so protective layer is quickly constructed around the active material as reported by Jafari et al. (2008).

Bringas-Lantigua et al. (2011) and Adamiec and Kalemba, (2006) reported similar findings for moisture content while working with and menhaden oil (1.96-2.54\%) and essential oil (1.70-4.16\%) respectively. Wall material and its ratio with the oil has significant effect on the moisture content. Shao et al. (2018) observed that increase of solid content at 0.3 ratio in algal oil altered the viscosity toward high value that resulted in low moisture content due to unavailability of water for evaporation. In another study conducted by Bae and Lee (2008) on avocado oil spray drying wettability was ranged between 457-1083s. High microencapsulation efficiency is also related to total solid content. Increase in solid content of emulsion resulted in low moisture content that produced microcapsules with high efficiency as compared to other treatments. Huynh et al. (2008) reported similar results while working with lemon oil and used maltodextrin and whey protein concentrate as wall material. Linke et al. (2021) found that non encapsulated oil is dependent on oil load and its quantity is positively correlated with the oil being used in emulsion. They further added that encapsulation efficiency is a way for determination of surface oil present over the shell of microcapsules.

Increasing oil concentration has a total negative effect on solubility as indicated from results. Free fish oil is not soluble in water as compared to capsules that is explained on the basis of coating material (maltodextrin and chitosan). Ahmed et al. (2010) reported solubility results ranging from $40.24 \%$ to $56.95 \%$. Encapsulation of coffee oil has hygroscopicity values $13.73-17.89 \%$ as reported by Frascareli et al. (2012). Fish oil hydrophobic nature resulting in low absorption which in turn produced low hygroscopicity (Wang and Zhou, 2012). Density is an important factor regarding packing of food-based materials. Microcapsule having high density were able to be stored in smaller vessels. Aghbashlo et al. (2012) reported similar results for bulk tapped density. Jinapong et al. (2008) worked on soymilk densities and observed values ranged between $0.30-0.35 \mathrm{~g} \mathrm{~mL}^{-1}$.

Results obtained in current study for PV were similar as compared to other studies related to microencapsulation of fish oil. Drusch and Berg (2008) prepared fish oil microcapsules with $30 \%$ and 50\% load using starch as coating material and reported PV ranged between 160$340 \mathrm{meq} \mathrm{O2} / \mathrm{kg}$ oil. Similarly, fish protein hydrolysates and glucose syrup were used as coating material by MoralesMedina et al. (2016) and they observed higher PV value (120-160 meq $\mathrm{O}_{2} / \mathrm{kg}$ oil) after 6 weeks of storage. It is supposed that higher PV values after 30 days of storage period noted for high oil content powder microcapsules resulted due to insufficient coating material as compared to wall material (Reineccius and Yan, 2016). So, oil was not protected by the matrix and non-encapsulated oil elevated PV due to its interaction with air oxygen. For the determination of secondary oxidation products ansidine value was recorded after different storage intervals. Results of the current study are in accordance with other studies found in literature. Increase in secondary oxidation products might be resulted due to changes in wall system and reaction with environmental oxygen (Sanchez-Reinoso and Gutierrez, 2017). Tonon et al. (2011) also reported higher values of oxidation for flaxseed oil microcapsules prepared with $40 \%$ oil load. Increased secondary oxidation products in microcapsules after 56 days of storage was found by Drusch and Berg (2008) for 50\% oil content as compared to $30 \%$. They further explained these readings on the basis of un-encapsulated oil present of surface. It was concluded that fish oil microcapsules having low concentration of fish oil were preserved these compounds due to efficient encapsulation of active material (Calvo et al., 2012). Changing in tocopherol content is attributed to emulsification conditions that produced free radicals and tocopherols consumed themselves.

\section{Conclusion}

Effect of oil concentration on emulasion properties, microencapsulation characteristics and oxidative stability at different storage intervals was studied. TFO microcapsules prepared with $10 \%$ and $20 \%$ oil load were suggested in terms of high oxidative stability during the storage period and shown good oxidatie properties. Fish odor and oxidation of oil was prevented through enveloping the oil in a coating materials and TFO-10\% concentration is concluded as optimum for enhancing shelf life of fish oil and microcapsulescan be used in fortification of food products. 


\section{Acknowledgements}

We acknowledge Higher Education Commission, (HEC) Islamabd for providing financial support of research project entitled "Sustainable Production of Processed Fish Meat and Value-Added Fish By-products" under Technology Development Fund. The work presented in this paper is part of a project sponsored under grant no. HEC-TDF03-301.

\section{References}

ADAMIEC, J. and KALEMBA, D., 2006. Analysis of microencapsulation ability of essential oils during spray drying. Drying Technology, vol. 24, no. 3, pp. 1127-1132. http://dx.doi. org/10.1080/07373930600778288.

AGHBASHLO, M., MOBLI, H., RAFIEE, S. and MADADLOU, A., 2012. Optimization of emulsification procedure for mutual maximizing the encapsulation and exergy efficiencies of fish oil microencapsulation. Powder Technology, vol. 225, pp. 107-117. http://dx.doi.org/10.1016/j.powtec.2012.03.040.

AGUIAR, A.C.D., SILVA, L.P.S., REZENDE, C.A.D., BARBERO, G.F. and MARTINEZ, J., 2016. Encapsulation of pepper oleoresin by supercritical fluid extraction of emulsions. The Journal of Supercritical Fluids, vol. 112, pp. 37-43. http://dx.doi.org/10.1016/j. supflu.2016.02.009.

AHMED, M., AKTER, M.S., LEE, J.C. and EUN, J.B., 2010. Encapsulation by spray drying of bioactive components, physicochemical and morphological properties from purple sweet potato. Lebensmittel-Wissenschaft + Technologie, vol. 43, no. 9, pp. 1307-1312. http://dx.doi.org/10.1016/j.lwt.2010.05.014.

AMERICAN OIL CHEMISTS' SOCIETY - AOCS, 1998. Official Method CE 8-89 1998: determination of tocopherols and tocotrienols in vegetable oils and fats by HPLC. Champaing: AOCS Press.

BAE, E.K. and LEE, S.J., 2008. Microencapsulation of avocado oil by spray drying using whey protein and maltodextrin. Journal of Microencapsulation, vol. 25, no. 8, pp. 549-560. http://dx.doi. org/10.1080/02652040802075682. PMid:18465295.

BAIK, M.Y., SUHENDRO, E.L., NAWAR, W.W., MCCLEMENTS, D.J., DECKER, E.A. and CHINACHOTI, P., 2004. Effects of antioxidants and humidity on the oxidative stability of microencapsulated fish oil. Journal of the American Oil Chemists' Society, vol. 81, no. 4, pp. 355-360. http://dx.doi.org/10.1007/s11746-004-0906-7.

BALK, E.M., LICHTENSTEIN, A.H., CHUNG, M., KUPELNICK, B., CHEW, P. and LAU, J., 2006. Effects of omega-3 fatty acids on serum markers of cardiovascular disease risk: a systematic review. Atherosclerosis, vol. 189, no. 1, pp. 19-30. http://dx.doi. org/10.1016/j.atherosclerosis.2006.02.012. PMid:16530201.

BARROS FERNANDES, R.V., MARQUES, G.R., BORGES, S.V. and BOTREL, D.A., 2014. Effect of solids content and oil load on the microencapsulation process of rosemary essential oil. Industrial Crops and Products, vol. 58, pp. 173-181. http://dx.doi. org/10.1016/j.indcrop.2014.04.025.

BLIGH, E.G. and DYER, W.J., 1959. A rapid method of total lipid extraction and purification. Canadian Journal of Biochemistry and Physiology, vol. 37, no. 8, pp. 911-917. http://dx.doi.org/10.1139/ 059-099. PMid:13671378.

BOEREKAMP, D.M.W., ANDERSEN, M.L., JACOBSEN, C., CHRONAKIS, I.S. and GARCIA-MORENO, P.J., 2019. Oxygen permeability and oxidative stability of fish oil-loaded electrosprayed capsules measured by Electron Spin Resonance: effect of dextran and glucose syrup as main encapsulating materials. Food Chemistry, vol. 287, pp. 287-294. http://dx.doi.org/10.1016/j. foodchem.2019.02.096. PMid:30857702.
BRINGAS-LANTIGUA, M., EXPOSITO-MOLINA, I., REINECCIUS, G.A., LÓPEZ-HERNÁNDEZ, O. and PINO, J.A., 2011. Influence of spray-dryer air temperatures on encapsulated mandarin oil. Drying Technology, vol. 29, no. 5, pp. 520-526. http://dx.doi.or g/10.1080/07373937.2010.513780.

CAI, Y.Z. and CORKE, H., 2000. Production and properties of spray-dried Amaranthus betacyanin pigments. Journal of Food Science, vol. 65, no. 7, pp. 1248-1252. http://dx.doi. org/10.1111/j.1365-2621.2000.tb10273.x.

CALVO, P., CASTANO, A.L., LOZANO, M. and GONZALEZ-GOMEZ, D., 2012. Influence of the microencapsulation on the quality parameters and shelf-life of extra-virgin olive oil encapsulated in the presence of BHT and different capsule wall components. Food Research International, vol. 45, no. 1, pp. 256-261. http:// dx.doi.org/10.1016/j.foodres.2011.10.036.

CANO-CHAUCA, M., STRINGHETA, P.C., RAMOS, A.M. and CALVIDAL, J., 2005. Effect of the carriers on the microstructure of mango powder obtained by spray drying and its functional characterization. Innovative Food Science \& Emerging Technologies, vol. 6, no. 4, pp. 420-428. http://dx.doi. org/10.1016/j.ifset.2005.05.003.

CHANG, C.P., LEUNG, T.K., LIN, S.M. and HSU, C.C., 2006. Release properties on gelatin-gum Arabic microcapsules containing camphor oil with added polystyrene. Colloids and Surfaces, vol. 50, no. 2, pp. 136-140. http://dx.doi.org/10.1016/j. colsurfb.2006.04.008. PMid:16797942.

DRUSCH, S. and BERG, S., 2008. Extractable oil in microcapsules prepared by spray-drying: Localisation, determination and impact on oxidative stability. Food Chemistry, vol. 109, no. 1, pp. 17-24. http://dx.doi.org/10.1016/j.foodchem.2007.12.016. PMid:26054260.

FRASCARELI, E.C., SILVA, V.M., TONON, R.V. and HUBINGER, M.D., 2012. Effect of process conditions on the microencapsulation of coffee oil by spray drying. Food and Bioproducts Processing, vol. 90 , no. 3, pp. 413-424. http://dx.doi.org/10.1016/j.fbp.2011.12.002.

GALEANO DÍAZ, T., DURÁN-MERÁS, I., RODRÍGUEZ CÁCERES, M.I. and ROLDAN MURILLO, B., 2006. Comparison of different fluorimetric signals for the simultaneous multivariate determination of tocopherols in vegetable oils. Applied Spectroscopy, vol. 60, no. 2, pp. 194-202. http://dx.doi.org/10.1366/000370206776023449. PMid: 16542571

GANESAN, B., BROTHERSEN, C. and MCMAHON, D.J., 2014. Fortification of foods with omega-3 polyunsaturated fatty acids. Critical Reviews in Food Science and Nutrition, vol. 54, no. 1, pp. 98-114. http://dx.doi.org/10.1080/10408398.2011.5 78221. PMid:24188235.

GOULA, A.M. and ADAMOPOULOS, K.G., 2008. Effect of maltodextrin addition during spray drying oftomato pulp in dehumidified air. II. Powder properties. Drying Technology, vol. 26, no. 6, pp. 726-737. http://dx.doi.org/10.1080/07373930802046377.

HUYNH, T.V., CAFFIN, N., DYKES, G.A. and BHANDARI, B., 2008. Optimization of the microencapsulation of lemon myrtle oil using response surface methodology. Drying Technology, vol. 26, no. 3, pp. 357-368. http://dx.doi.org/10.1080/07373930801898182.

JAFARI, S.M., ASSADPOOR, E., HE, Y. and BHANDARI, B., 2008. Encapsulation efficiency of food flavours and oils during spray drying. Drying Technology, vol. 26, no. 7, pp. 816-835. http:// dx.doi.org/10.1080/07373930802135972.

JINAPONG, N., SUPHANTHARIKA, M., JAMNONG, P., 2008. Production of instant soymilk powders by ultrafiltration, spray drying and fluidized bed agglomeration. Journal of Food Engineering, vol. 84, no. 2, pp. 194-205. https://doi.org/10.1016/j. jfoodeng.2007.04.032.<jrn> 
KAK, A., BAJAJ, P.R., BHUNIA, K., NITIN, N. and SABLANI, S.S., 2019. A fluorescence-based method for estimation of oxygen barrier properties of microspheres. Journal of Food Science, vol. 84, no. 3, pp. 532-539. http://dx.doi.org/10.1111/1750-3841.14453. PMid:30730581.

LABUSCHAGNE, P., 2018. Impact of wall material physicochemical characteristics on the stability of encapsulated phytochemicals: A review. Food Research International, vol. 107, pp. 227-247. http://dx.doi.org/10.1016/j.foodres.2018.02.026. PMid:29580481.

LAZKO, J., POPINEAU, Y. and LEGRAND, J., 2004. Soy glycinin microcapsules by simple coacervation method. Colloids and Surfaces, vol. 37, no. 1-2, pp. 1-8. PMid:15450301.

LINKE, A., WEISS, J. and KOHLUS, R., 2021. Impact of the oil load on the oxidation of microencapsulated oil powders. Food Chemistry, vol. 341, no. Pt 1, 128153. PMid:33027754.

MARTIN, A., VARONA, S., NAVARRETE, A. and COCERO, M.J., 2010. Encapsulation and co-precipitation processes with supercritical fluids: applications with essential oils. The Open Chemical Engineering Journal, vol. 4, no. 1, pp. 31-41. http://dx.doi.org/1 $0.2174 / 1874123101004010031$.

MORALES-MEDINA, R., TAMM, F., GUADIX, A.M., GUADIX, E.M. and DRUSCH, S., 2016. Functional and antioxidant properties of hydrolysates of sardine (S. pilchardus) and horse mackerel (T. mediterraneus) for the microencapsulation of fish oil by spray-drying. Food Chemistry, vol. 194, pp. 1208-1216. http:// dx.doi.org/10.1016/j.foodchem.2015.08.122. PMid:26471673.

ONWULATA, C.I., 2013. Microencapsulation and functional bioactive foods. Journal of Food Processing and Preservation, vol. 37, no. 5 , pp. 510-532. http://dx.doi.org/10.1111/j.1745-4549.2012.00680.x.

POURASHOURI, P., SHABANPOUR, B., RAZAVI, S.H., JAFARI, S.M., SHABANI, A. and AUBOURG, S.P., 2014. Impact of wall materials on physicochemical properties of microencapsulated fish oil by spray drying. Food and Bioprocess Technology, vol. 7, no. 8, pp. 2354-2365. http://dx.doi.org/10.1007/s11947-013-1241-2.

PRASHANTH, K.V.H. and THARANATHAN, R.N., 2007. Chitin/chitosan: modifications and their unlimited application potential-an overview. Trends in Food Science \& Technology, vol. 18, no. 3, pp. 117-131. http://dx.doi.org/10.1016/j.tifs.2006.10.022.

RAHMANI-MANGLANO, N.E., GONZALEZ-SANCHEZ, I., GARCIAMORENO, P.J., ESPEJO-CARPIO, F.J., JACOBSEN, C. and GUADIX, E.M., 2020. Development of fish oil-loaded microcapsules containing whey protein hydrolysate as film-forming material for fortification of low-fat mayonnaise. Foods, vol. 9, no. 5, pp. 545. http://dx.doi.org/10.3390/foods9050545. PMid:32365987.

RAY, S., RAYCHAUDHURI, U. and CHAKRABORTY, R., 2016. An overview of encapsulation of active compounds used in food products by drying technology. Food Bioscience, vol. 13, pp. 76-83. http://dx.doi.org/10.1016/j.fbio.2015.12.009.

REINECCIUS, G.A. and YAN, C., 2016. Factors controlling the deterioration of spray dried flavourings and unsaturated lipids. Flavour and Fragrance Journal, vol. 31, no. 1, pp. 5-21. http:// dx.doi.org/10.1002/ffj.3270.

SANCHEZ-REINOSO, Z. and GUTIERREZ, L.F., 2017. Effects of the emulsion composition on the physical properties and oxidative stability of Sacha Inchi (Plukenetia volubilis L.) oil microcapsules produced by spray drying. Food and Bioprocess Technology, vol. 10, no. 7, pp. 1354-1366. http://dx.doi.org/10.1007/s11947017-1906-3.

SANSONE, F., MENCHERINI, T., PICERNO, P., D’AMORE, M., AQUINO, R.P. and LAURO, M.R., 2011. Maltodextrin/pectin microparticles by spray drying as carrier for nutraceutical extracts. Journal of Journal of Food Engineering, vol. 105, no. 3, pp. 468-476. http:// dx.doi.org/10.1016/j.jfoodeng.2011.03.004.

SHAO, W., PAN, X., LIU, X., TENG, F. and YUAN, S., 2018. Microencapsulation of algal oil using spray drying technology. Food Technology and Biotechnology, vol. 56, no. 1, pp. 65-70. http://dx.doi.org/10.17113/ftb.56.01.18.5452. PMid:29795998.

TONON, R.V., GROSSO, C.R.F. and HUBINGER, M.D., 2011. Influence of emulsion composition and inlet air temperature on the microencapsulation of flaxseed oil by spray drying. Food Research International, vol. 44, no. 1, pp. 282-289. http://dx.doi. org/10.1016/j.foodres.2010.10.018.

TROESCH, B., EGGERSDORFER, M., LAVIANO, A., ROLLAND, Y., SMITH, A.D., WARNKE, I., WEIMANN, A. and CALDER, P.C., 2020. Expert opinion on benefits of long-chain omega-3 fatty acids (DHA and EPA) in aging and clinical nutrition. Nutrients, vol. 12, no. 9, pp. 2555. http://dx.doi.org/10.3390/nu12092555. PMid:32846900.

TURCHIULI, C., FUCHS, M., BOHIN, M., CUVELIER, M.E., ORDONNAUD, C., PEYRAT-MAILlARD, M.N. and DUMOULIN, E., 2005. Oil encapsulation by spray drying and fluidized bed agglomeration. Innovative Food Science E' Emerging Technologies, vol. 6, no. 1, pp. 29-35. http://dx.doi.org/10.1016/j.ifset.2004.11.005.

TZANG, B.S., YANG, S.F., FU, S.G., YANG, H.C., SUN, H.L. and CHEN, Y.C., 2009. Effects of dietary flaxseed oil on cholesterol metabolism of hamsters. Food Chemistry, vol. 114, no. 4, pp. 1450-1455. http://dx.doi.org/10.1016/j.foodchem.2008.11.030.

VISHNU, K.V., CHATTERJEE, N.S., AJEESHKUMAR, K.K., LEKSHMI, R.G., TEJPAL, C.S., MATHEW, S. and RAVISHANKAR, C.N., 2017. Microencapsulation of sardine oil: application of vanillic acid grafted chitosan as a bio-functional wall material. Carbohydrate Polymers, vol. 174, pp. 540-548. http://dx.doi.org/10.1016/j. carbpol.2017.06.076. PMid:28821102.

WANG, W. and ZHOU, W., 2012. Characterization of spray-dried soy sauce powders using maltodextrins as carrier. Journal of Food Engineering, vol. 109, no. 3, pp. 399-405. http://dx.doi. org/10.1016/j.jfoodeng.2011.11.012.

WENYAO, S.H.A., MENGWEN, Y.A.N., QUANLING, X.I.E. and XUESHAN, P.A.N., 2016. Microencapsulation of DHA algal oil by spray drying. In: International Conference on Biological Engineering and Pharmacy, 2016, Shanghai, China. Zhengzhou: Atlantis Press.

YU, C., WANG, W., YAO, H., LIU, H., 2007. Preparation of phospholipid microcapsule by spray drying. Drying Technology, vol. 25, no. 4, pp. 695-702. https://doi.org/10.1080/07373930701291017.

YULIANI, S., TORLEY, P.J., DARCY, B., NICHOLSON, T. and BHANDARI, B., 2006. Extrusion of mixtures of starch and D-limonene encapsulated with b-cyclodextrin: flavour retention and physical properties. Food Research International, vol. 39, no. 3, pp. 318-331. http://dx.doi.org/10.1016/j.foodres.2005.08.005. 